\title{
"O EXÉRCITO DOS MORTOS": SENTIDO DO SACRIFÍCIO E DA TRANSCENDENTALIDADE NA MILITÂNCIA REVOLUCIONÁRIA, CASO DO EXÉRCITO DE LIBERTAÇÃO NACIONAL (ELN) DA COLÔMBIA*
}

Andrea Lissett Pérez

\section{Introdução}

Neste artigo discuto a presença de elementos religiosos no interior de um grupo revolucionário da Colômbia, o Exército de Libertação Nacional (ELN), surgido na efervescência da Revolução Cubana nos anos 1960 e que ainda segue vigente como projeto de luta armada. O interesse por esta temática emergiu no percurso da pesquisa etnográfica que buscava elucidar as razões pelas quais este grupo tem perdurado por mais de 40 anos como sujeito ativo de complexas dinâmicas sociais e políticas em distintas regiões do território colombiano. Tendo presente que a maioria dos grupos nascidos nesse período se extinguiu pouco tempo após sua fundação, tem ainda maior relevo a compreensão da longa duração do ELN. Por que continua vigente? Que elementos permitiram ou facilitaram essa permanência histórica?

Os dados etnográficos compilados durante os anos 2006 e $2007^{1}$ me permitiram detectar aspectos instigantes, como a existência de uma importante tradição de luta e resistência social pela via armada nos setores subalternos colombianos, assim como um significativo processo de construção identitária no interior do grupo. Esta foi uma descoberta de fato relevante porque, de um lado, mostrava-se o peso da história, da tradição que seguia nutrindo de sentido o agir social e, neste caso, o surgimento de novas propostas de luta e, de outro, o papel que desempenhava o simbólico, frequentemente ignorado e/ou subestimado no campo de estudo sobre a problemática do conflito e dos atores armados. ${ }^{2}$

O certo é que me deparei com uma identidade diferenciada, denominada por seus próprios militantes como o ser eleno, ou ser parte das três letras: E-L-N, ou ser "vermelho e preto" como as cores de sua bandeira; uma identidade que carregam com orgulho e que fala de algo íntimo, de 
sua história, de suas vivências, de seus ideais e de tudo o que envolve seu projeto de vida. Era um sentimento forte, expresso em distintos âmbitos, em sujeitos de diferentes procedências e subjetividades, e que os integrava, os irmanava, apesar das diferenças e das distâncias; era o que os fazia sentirem-se parte do que de fato mantinha o grupo como tal.

Vários elementos se mostraram preeminentes na formação da identidade dos elenos, tais como os laços de familiaridade que se criam entre os militantes ou o sentido de pertença que se forja através da vida gregária e dos fios da memória coletiva, assim como a presença, nada desprezível, do religioso. Ainda que a organização se defina como ateia e seguidora dos princípios científicos do marxismo-leninismo, em seus discursos e em sua prática podiam ler-se significativos traços religiosos. O que é esse religioso? Como se manifesta?

Aqui é importante trazer à tona alguns dados históricos que permitam contextualizar esse processo. Transcorriam os anos 1960, fervia a utopia revolucionária pelo continente e a tomada do poder e a construção de uma sociedade socialista passaram a ser uma possibilidade imediata e prioritária. Esse será o novo paradigma político da esquerda, entendido, conforme McAdam (1994), como o "marco dominante de protesto", que legitimará a ação coletiva em prol dos ideais revolucionários. É importante salientar o profundo impacto desse novo marco ideológico não só em relação aos poderes estabelecidos, mas também nos velhos partidos de esquerda e, principalmente, nos partidos comunistas, que foram fortemente questionados quanto às suas estratégias e táticas de luta.

Esse movimento de crítica e renovação levou à formação de novas organizações políticas que foram identificadas como a "nova esquerda", que se caracterizou pela radicalização em sua concepção política e pela defesa das "formas superiores de luta", isto é, a luta armada (Arenas 1971). A essas novas propostas de luta e utopias libertárias se vincularam distintos setores sociais, como camponeses, intelectuais, operários, estudantes e também cristãos que, desde as periferias da instituição eclesiástica, assumem, além da "centralidade dos pobres e oprimidos, a urgência de sua libertação" (Boff 1996:10).

Nesse ambiente, surge o ELN sob a iniciativa de sete estudantes que viajam a Havana e formam um grupo denominado Brigada Pró-Libertação Antonio Galán com o objetivo de "retornar ao país e impulsionar a luta revolucionária, organizando, conjuntamente com a atividade política, os grupos que na cidade e no campo desenvolveram a luta armada" (Arenas 1971:16). Esses foram os primeiros passos da organização, que nasce publicamente em 1965 com a tomada do povoado de Simacota. Constitui-se como uma guerrilha revolucionária de caráter político-militar, enquadrada nos pos- 
tulados da "nova esquerda", e cujo discurso político apelava para termos simples e acessíveis à população comum, evocando tradições políticas de importante ascendência popular, assim como um profundo sentido nacionalista de luta pela "libertação nacional", que trazia um significativo valor de unidade e identidade, bandeira de luta de fundamentais mobilizações sociais na Colômbia. O ELN se mostrava, assim, como uma opção ampla na qual "todos" cabiam.

E, com efeito, o discurso demonstrou ser eficaz, pois para essa proposta revolucionária confluíram distintos setores sociais que se sentiram incluídos e identificados. Entre eles, o carismático sacerdote Camilo Torres ${ }^{3}$ que, por suas ideias e ativismo em prol das diferentes problemáticas sociais, tinha sido afastado pelo setor conservador da instituição religiosa. Camilo tinha uma grande acolhida popular, a ponto de fundar um exitoso, ainda que breve no tempo (1963-1964), movimento político nacional — Frente Unido — para liderar as mudanças requeridas "na estrutura do poder político e que as maiorias possam produzir as decisões" (Torres apud Arenas 1971:67). Nesse contexto sociopolítico, a organização se aproximou deste líder e convidouo a participar do projeto do ELN. Uma série de acontecimentos favoreceu a incorporação do sacerdote à guerrilha, tais como seu desencanto com as possibilidades de mudança social pelas vias institucionais ao não encontrar receptividade nos âmbitos burocráticos, a influência do marco dominante de protesto que privilegiava a luta armada, e as contínuas ameaças à sua vida.

Camilo ingressou no corpo armado da guerrilha em fins de 1965 e morreu em fevereiro de 1966, no primeiro combate de que participou, ao tentar tomar a arma de um soldado inimigo. Este fato teve um grande impacto imediato, pois tudo o que Camilo representava como figura pública e líder político incidiu sobre a opção revolucionária pela via armada e, particularmente, pelo ELN. Muitos de seus seguidores, simpatizantes e amigos ingressaram nas fileiras deste grupo (Arenas 1971). Mas o principal efeito, no que se refere ao processo organizativo do ELN, seria a abertura de um espaço de participação e de compromisso político do setor dos cristãos (clérigos e laicos), identificados com o pensamento e o exemplo de vida de Camilo.

Isto não significa, é importante aclarar, que a organização se tornou cristã ou adotou o cristianismo como fonte ideológica da luta revolucionária, pois, como já dito, se define como ateia e seguidora do marxismo-leninismo. Este é, justamente, o miolo da presente reflexão: a forma como o religioso permeia a organização para além dos aspectos formais ou das declarações ideológicas. Trata-se, então, de uma religiosidade profunda que é necessário desentranhar e que se relaciona com as atitudes, os valores e certa moralidade que orientam a maneira de ser e de agir desses militantes. 


\section{Presença do religioso}

O setor dos cristãos deixou rastros indeléveis no ELN. Nesse processo em que entraram, passaram e, muitos deles, ficaram no ELN, não só se mesclaram indivíduos, mas sobretudo subjetividades. No entanto, chama a atenção o desconhecimento desse universo simbólico na formação de seu pensamento. Em seus discursos formais, o ELN se concebe fora dessa tradição. Define-se com base no paradigma revolucionário e racionalista, como uma organização ateia que se orienta pela concepção científica do marxismo-leninismo. Este é um princípio que não se discute e que tem permanecido intacto ao longo da história do grupo.

Inclusive, num dos momentos mais tensos, quando foi debatida a compatibilidade entre o marxismo e o cristianismo com o fim de esclarecer a "verdadeira" orientação ideológica do ELN, o sacerdote e então chefe máximo da organização - Manuel Pérez - afirmou: "É indiscutível que a ciência para a revolução é o marxismo-leninismo, e isso é assumido por todos os cristãos participantes na organização" (Manuel apud Harnecker 1988:13). Está claro que a "ciência", entendida no marco do marxismo-leninismo, é assumida como a fonte do saber, numa lógica que parece ser constante entre as organizações deste tipo, assim como assinala Marcelo Camurça em seu estudo sobre os movimentos e as organizações comunistas: "o campo marxista se torna um lugar por excelência onde se explicam todas as coisas" (1988:30).

Dessa maneira, o conhecimento científico, e nesse caso o paradigma dominante das organizações de esquerda, termina convertendo-se numa verdade inquestionável, uma espécie de "ato de fé", atrás do qual, paradoxalmente, escudam-se e coexistem distintos registros, como o religioso que, embora seja negado, continua influenciando a construção social da realidade. Este ponto requer algumas precisões conceituais porque toca numa das fibras mais sensíveis da sociedade moderna: o questionamento de seu ideário de mundo secularizado, racional, construído sobre a separação radical entre o religioso e o laico. Apesar da fixidez dessa mentalidade no mundo ocidental, a irrupção de novas realidades sociais, de diferentes expressões sociais, culturais e intelectuais não classificáveis dentre essas categorias colocou em relevo a existência de diversas formas de hibridismos e reinvenções simbólicas fora da linearidade do processo de secularização, da fronteira entre o religioso e o laico.

Essa nova perspectiva parecia indicar, assim, que na prática não existe um divórcio tão abismal entre os discursos religiosos e racionais, tal como se pensava sob o ideal da modernidade e como a maioria dessas organizações de esquerda termina por acreditar e defender. Talvez essas linguagens 
estejam mais misturadas do que aparentam ou se tenta aparentar, e por isso seja necessário, como convida Luis Eduardo Soares (1990), sair dos limites da oposição desses domínios, apreender distintas variáveis e pensar numa interação dialógica de fluxos, intercâmbios, apropriação de elementos, enfim, em um movimento criador com base nas diferenças não excludentes. $\mathrm{Ou}$, indo ainda mais longe nesse debate, questionar os princípios que estão na base da visão moderna da religião e da secularização, e pensar, como propõe Otávio Velho (1995), que provavelmente a separação desses universos não seja tão certa, que a questão não estaria no fato de a religião deixar ou não de ser o fundamento das sociedades humanas, conforme aborda Marcel Gauchet (2004), mas se estas possuem realmente um fundamento.

Este é, então, o cerne do problema que se apresenta em relação à fachada racionalista que os elenos construíram como parte de um discurso de legitimação ante si mesmos e ante os demais, mas que na prática não parece coincidir com suas formas concretas de atuar. Ali estão presentes os rastros da religiosidade. O legado do setor dos cristãos e principalmente dos clérigos que exerceram papéis determinantes na vida da organização penetrou distintos planos de sua realidade. Por mais que se declarem marxistas-leninistas, sua lógica de comportamento mostra o profundo sentido do religioso que os acompanha. O curioso deste fato é que não foi uma aposta intencional ou consciente, pelo contrário, como podemos perceber na voz do sacerdote Manuel Pérez, pois eles praticamente renunciaram à condição religiosa para assumir o exercício da militância. Foi através do estilo particular com que esse setor encarou a luta revolucionária que a subjetividade religiosa se inseriu e ganhou dinâmica própria no interior do ELN.

Aqui é preciso trazer à tona um fato, já mencionado, que marca profundamente a organização: a morte em combate do sacerdote Camilo Torres, que o transforma em mártir da revolução e em mito reverencial para o ELN. O fundo religioso deste episódio é evidente e neste ponto reside sua força. Camilo interpretou e atualizou um dos mais caros preceitos do cristianismo: o sentido do sacrifício e da entrega total pelos outros. Ele encarna esse princípio, esse ato germinal da tradição cristã — o sacrifício de Jesus pela humanidade — cuja mensagem é traduzida para a linguagem da luta social:

Quando Jesus ia para Jerusalém disse aos apóstolos: "Olhem, a mim ninguém tira a vida, eu a entrego voluntariamente". E a entregou voluntariamente, porque com essa entrega, com esse grito enorme perdido no Calvário, Jesus de Nazaré ia gritando a toda a humanidade: vale a pena morrer quando se trata de construir a fraternidade universal (Sacerdote Bernardo Arroyabe, militante do ELN, 1996). 
Esta foi a exegese feita por Camilo, levada até as últimas consequências: o sentido de que não há maior prova de amor pelo próximo que o próprio sacrifício. Este é, sem dúvida, um dos maiores impactos desse líder, que sensibiliza e convoca muitos cristãos, entre os quais cabe mencionar os sacerdotes espanhóis Manuel Pérez, Domingo Ladin e José Antonio Jimenez, que se uniram às fileiras do ELN em 1970. Eis um dado importante, pois ainda que tenham sido vários os clérigos que ingressaram na guerrilha, eles não apenas foram os primeiros a dar esse passo, mas também a ocupar altos cargos, como é o caso de Manuel Pérez, que foi comandante máximo da organização de 1983 até a sua morte, em 1998. Eles foram os herdeiros do fenômeno representado por Camilo, de seus princípios de luta e de sua vocação de entrega à revolução. A morte de Ladin em combate e a profunda convicção de Manuel durante toda a sua militância ampliaram e reforçaram a visão sacrificialista inaugurada por Camilo. Uma boa ilustração da forma como esses sacerdotes interpretaram o compromisso revolucionário pode ser observada na mensagem de Domingo Ladin anunciando publicamente sua incorporação ao ELN:

\begin{abstract}
Ao tornar pública esta decisão, renovo o compromisso irrevogável aceito ao ser ordenado sacerdote de consagração. Acredito que agora começa minha autêntica consagração sacerdotal, que exige o sacrifício total para que todos os homens vivam em plenitude. Não é mera coincidência que este anúncio seja feito no dia em que o povo colombiano celebra o quarto aniversário da morte física do grande líder de nosso povo: Camilo Torres Restrepo. Sua palavra e exemplo seguem sendo bandeiras de redenção, grito de esperança para os explorados [...] Camilo não morreu. Vive no coração dos pobres e oprimidos, no interior de todo homem que luta pela justiça e fraternidade humanas (Ladin em 15 de fevereiro de 1970).
\end{abstract}

Ladin sintetiza três elementos pertinentes para a presente análise: o sentido do sacrifício como premissa da luta revolucionária, a consagração do mito de Camilo como redentor do povo que, de alguma maneira, estende-se a eles como continuadores da luta, e o caráter de transcendentalidade que se conquista após o sacrifício. O trabalho de campo permitiu-me constatar que essas noções não só foram apropriadas pelo setor dos cristãos, mas se converteram em importantes pilares na construção do sentido de militância do grupo:

Tenho medo de ficar sozinha, pois com o passar do tempo a maioria dos meus familiares caiu nessa luta. Tenho consciência que eu também ficarei aqui, porque 
meu amor é entregar minha vida por isto. Gostaria que meus filhos seguissem a mesma consciência, é a origem, a moral de minha família (Talia, camponesa, 22 anos de militância).

Como podemos perceber, essa guerrilheira concebe a morte como algo desejado, como um fim cheio de significado, como uma expressão de amor que tem uma conotação forte, íntima, familiar, porque envolve não só seus parentes, mas seus próprios filhos, nos quais deposita a esperança de continuidade da luta. Esse foi um traço reiterativo nas distintas perspectivas subjetivas e condições de militância. Assim, por exemplo, refere uma guerrilheira de origem urbana de longa trajetória: "é encher-se de todos esses atos que dão valor a um princípio e que você chama de amor ao povo, sua razão de ser. Porque você diz: eu luto e dou minha vida para que a luta mude as condições de vida desse povo".

Ainda que haja neste último caso um discurso mais racional sobre os objetivos da luta, no fundo estão em jogo os mesmos valores: o sujeito que se sacrifica, a atitude de entrega como um ato de amor e os receptores dessa entrega, o povo. Eis o valor do sacrifício, sublimado e profundamente inserido na subjetividade dos militantes elenos. Com base em tal constatação, é importante aprofundar a lógica deste tipo de sacrifício. A hipótese, já esboçada, é a de que se trata de uma recriação simbólica do mito de salvação da tradição cristã, numa versão moderna do Cristo redentor, que reveste os militantes com uma auréola de sacralidade dimensionada em dois papéis transcendentais: o de salvadores, em vida, e o de mártires, após a morte. Vejamos.

\section{O sentido de ser salvador}

O ser salvador envolve várias condições. Em primeiro lugar, a disposição de deslocar-se de si mesmo, de colocar-se no lugar dos outros, de assumir suas penas e dores. Postura que exige a anulação do sentido do indivíduo entendido na perspectiva da modernidade, de ser o eixo da história, conforme indica Dumont: "ser moral, independente, autônomo, e por consequência essencialmente não social, que veicula os nossos valores supremos e ocupa o primeiro lugar na nossa ideologia moderna do homem e da sociedade" (1992:35).

Esse é um elemento-chave na compreensão do processo de construção identitária dos elenos: a confrontação com o individualismo tão fortemente arraigado na sociedade capitalista, e a reconstrução, em seu lugar, de um novo sentido de ser cujo epicentro seja o outro, isto é, um mundo visto e 
valorado a partir dos demais, como se pode constatar na fala da guerrilheira: "o amor ao povo é a razão de ser da gente". Daí que se possa pensar na existência de uma identidade fundamentada na outridade, na qual o sentido do ser é conquistado para os outros e através deles.

A segunda condição de ser salvador está relacionada com a forma como se concebem os outros, os sujeitos nos quais recai a ação salvadora, neste caso, o "povo". Uma categoria que, se conceitualmente já é bastante ambígua, no contexto político e ideológico em que é usada pela organização torna-se ainda mais difusa e polivalente. Em sua linguagem corriqueira, em suas campanhas ideológicas, em seus textos de divulgação e, inclusive, em muitos de seus documentos programáticos e de formação, não está claro o sentido de "povo". Aparece como um ente abstrato, incorpóreo, uma metáfora carregada de significado fundamentalmente emotivo e moral. A título de exemplo, observemos este fragmento de um pronunciamento do máximo comandante, Nicolás Rodriguez:

Nós estamos na corrente libertadora dos povos e é claro que muitos desafios e dificuldades estão por vencer [...] a razão pela qual nos levantamos em armas, na busca de propósitos mais justos, mais nobres e mais dignos para nosso povo [...] Há um tema muito importante em relação à legitimidade: nossa relação com o povo, com as massas. Uma frase muito sábia e bastante difundida pelos revolucionários vietnamitas diz que quem ganhar a mente e o coração do povo, ganhará a guerra (Nicolás Rodríguez em 2002, grifo meu).

Neste texto fica claro que o sujeito central é o "povo" e, ainda que seja nomeado de maneira recorrente, não é explícito o que ele significa, abarca ou refere. Entende-se que é objeto da luta, o fim e inclusive o meio, mas sempre num sentido abstrato, evocativo e enaltecedor. Não há forma de limitá-lo ou de defini-lo, simplesmente é o "outro" a quem se dirige a ação revolucionária e que, de alguma maneira, ocupa toda a razão do ser e do fazer. Nessa direção, poder-se-ia dizer que esse discurso está formulado sobre uma linguagem apologética, messiânica, fundamentada em unidades semânticas abrangentes e totalizantes que carregam de um caráter essencialista o sentido de ser e, por antonomásia, o sujeito da salvação.

O "povo" tem se mantido, desse modo, incólume como categoria central de seu pensamento político, desde seus primeiros pronunciamentos públicos: " [...] nosso povo, que tem sentido sobre suas costas o chicote da exploração, da miséria, da violência reacionária, levanta-se e está em pé de luta" (Manifiesto de Simacota 1964), até seus últimos documentos oficiais: "o compromisso no profundo amor pelo povo; na decisão inalterável de lutar até alcançar as 
transformações de que o povo e a nação necessitam para viver em paz, com bem-estar, democracia e dignidade" (Estatutos Internos 2006).

Outra característica bastante notória da forma como se referem ao "povo" é o tom carregado de emotividade: "o profundo amor pelo povo", "ganhar o coração do povo", que denota um relacionamento de tipo afetivo e que convoca a manifestações também emotivas, geradas pela força desses sentimentos atávicos que estão na base da moral cristã e que remetem a um valor essencial: o amor, valor que constituiu um dos pilares da interpretação feita por Camilo do cristianismo e que fez carreira no interior da organização por meio de uma expressão bastante significativa: o "amor eficaz", explicado assim por Camilo: "O principal no catolicismo é o amor ao próximo [...] Para que esse amor seja verdadeiro é preciso buscar a eficácia" (1965). Isto implica, então, que para o amor ser "verdadeiro" deve ter resultados na prática, deve mobilizar-se a favor do outro; este é o sentido da ação revolucionária em nome do "povo".

Nesse mesmo terreno do emotivo é possível perceber a presença de uma série de valores que aludem à noção de "povo": os despossuídos, os explorados, os pobres, os miseráveis, os oprimidos, os sofridos que apontam para uma situação de desamparo, de desvalia, de serem sujeitos-vítimas e, por consequência, alvos fundamentais da salvação. Eis a justificativa da ação salvadora do projeto revolucionário. Aqui, novamente, atua a força do emocional, mas também uma ética imanente que evoca per se a "bondade" do povo, derivada de sua condição de injustiça e que o leva a ser, de alguma maneira, ressarcido, enaltecido e, em última instância, idolatrado. Fato que pode ser explicado em razão de que aqui o social está substituindo o divino, adquirindo as qualidades dessa força absoluta, potencializada, que se torna a razão de ser e, como tal, aquilo pelo qual se está disposto a dar tudo, inclusive a vida.

Finalmente, é importante levar em consideração a forma como se concebe e assume a condição de ser salvador, ou seja, a formação dessa subjetividade sustentada na figura do messias. Nesse caminho, um elemento-chave para esta reflexão é o processo de ingresso na organização, que até meados dos anos 1980 foi bastante meticuloso e exigente:

Demoravam-se anos para recrutar alguém, no mínimo dois ou três. Era preciso conhecer as pessoas muito bem, você se tornava parte da família. Discutiam acerca de tua vida e de teu pensamento, tuas virtudes, teus defeitos, teus erros e, depois, te reconheciam, mas durante todo esse tempo não te diziam nada e esperavas com ansiedade. Logo te levavam a uma reunião e apareciam encapuzados, tu também, era um ritual (Pacho, intelectual, ex-militante). 
Apesar de ainda se conservar parte do ritual de ingresso nesta organização, até os anos 90 era um processo muito rígido. Fazer parte do ELN era um desafio que requeria inúmeras qualidades dos candidatos. Eram escolhidos por um membro do grupo que observava os comportamentos dos elegíveis e dava os sinais correspondentes no momento "oportuno". Durante essa fase de espera, aguardavam com muita ansiedade o resultado. Por isso, quando ingressavam efetivamente na organização, experimentavam um sentimento de altivez, de serem especiais em relação ao resto dos indivíduos. Ali começava a se formar a noção de que eram os elegidos, os destinados a, sentimento que ia aumentando à medida que tomavam consciência da missão para a qual haviam sido designados: serem salvadores do "povo explorado e oprimido".

Essa forma de entender a militância enche de sentido suas vidas e lhes proporciona grande parte da força para permanecerem, apesar das situações de dificuldade e de risco constantes. Eles possuem razões de muito peso para se manterem na luta, razões estas relacionadas nada menos com o "futuro da humanidade". Ainda que aparentemente possam ser vistos (pelos outros) como "pobres sacrificados" (ou noutras versões marginais, violentos), na verdade, eles se sentem superiores em virtude dessa missão transcendental com a qual estão comprometidos e que os envolve em sua condição existencial.

Eis o caráter messiânico subjacente a essa posição de salvadores, evidenciada nas distintas posturas políticas do grupo ao longo do tempo — bastante enfática no início (1964-1978), quando se consideravam a "vanguarda", ou seja, o grupo seleto mais consciente para levar adiante a revolução: "A guerrilha é a vanguarda combativa do povo [...] disposta a desenvolver uma série de ações bélicas tendentes a alcançar o único fim estratégico da guerra: a tomada do poder" (Revista Insurrección 1985:19).

Posteriormente, no período da reestruturação organizativa (anos 1980), revisam sua tendência ao vanguardismo: "A organização se sentia na vanguarda do processo revolucionário na Colômbia, sem ter em conta o nível de organização das massas" (Grupo O. Romero 1986:17). E mudam notoriamente sua postura, colocando-se em estreita relação com o povo: "Com a presente década se abrem em nosso país múltiplos caminhos de retificação estratégica que buscam lograr uma eficaz relação vanguardas-massa. Nela se coloca a organização de vanguarda ao serviço das massas" (Conclusões II Congresso 1990:82).

Todavia, no III Congresso, ano de 1996, realizam uma nova interpretação, assinalando que eles não eram o único grupo de "vanguarda revolucionária", que faziam parte de uma coletividade, tentando superar, assim, o profundo sectarismo característico das organizações de esquerda na Colômbia: 


\begin{abstract}
“Nas condições próprias de nossa Revolução, em que fazem presença várias organizações com projetos diversos, com acumulados históricos, militares e de massas, pensamos numa Vanguarda Coletiva" (Estatutos, III Congresso 1996:4). Esta é, em essência, a perspectiva de vanguarda que mantêm até hoje, tal como é registrada nas memórias de seu último Congresso, em que salientam: "a direção revolucionária" deve entender-se como a "construção de uma vanguarda coletiva capaz de incluir, unir e confluir para a luta por um novo governo" (Cadernos do Militante, IV Congresso 2006:3).

Embora a organização moderasse a perspectiva de se considerar a vanguarda do processo revolucionário, visualizando um papel mais ativo do "povo" e assumindo-se como parte de uma vanguarda coletiva, é necessário fazer algumas ressalvas. A primeira é que, contudo, segue considerando-se vanguarda, de modo que, por mais que atenue seus alcances, continua a se ver como guia do processo revolucionário, só que agora em um contexto mais complexo. A outra ressalva diz respeito à distância entre o que é dito ou o que pretende ser (nos discursos políticos) e o que acontece na prática, pois não parece estar muito clara a nova noção de vanguarda entre os próprios militantes: "O que é dirigir? Nisso não há suficiente clareza. O que significa construir embriões de poder popular? Quando perguntei isto aos companheiros, não souberam me responder o que isso significa" (Diário de campo 2007). Portanto, poder-se-ia afirmar que, apesar dos esforços realizados para mudar a visão vanguardista, é muito complicado transformar essa perspectiva sem afetar uma das principais matrizes que a alimentam: o messianismo de origem cristã, fortemente arraigado em sua mentalidade.
\end{abstract}

\title{
A morte como forma de transcendência
}

O problema da salvação não se esgota no plano da vida, transcende com a morte e adquire um poderoso sentido simbólico: o martírio, que é a forma ideal de se perpetuar na memória dos homens. Este foi o sentido ativado com a morte do sacerdote Camilo Torres, que forneceu a metáfora perfeita para dar vida à figura do martírio dentro da organização.

Uma das melhores sínteses deste pensamento está na parte de seu hino que diz: "Avancemos ao combate companheiros/ que estão vivas a consciência e a razão/ de Camilo o Comandante guerrilheiro/ com seu exemplo na insígnia/ nem um passo atrás/ libertação ou morte (NUPALOM)". Nesta estrofe há interessantes elementos para a presente reflexão. Em primeiro lugar, o fato de se chamar Camilo de "Comandante", como uma maneira de ressaltar a condição de guerrilheiro de um personagem socialmente significativo. 
Em segundo lugar, a sublimação de seu exemplo, que se torna um imperativo moral do dever ser, do caminho a seguir. E, em terceiro, a insígnia NUPALOM como uma ordem diante da qual não se discute nem se vacila e cuja mensagem é contundente: a entrega total, absoluta, em prol do ideal máximo (a libertação), na qual a morte aparece como um pressuposto "lógico", justificado, e inclusive desejado, enquanto contribui para esse ideal.

Nesses elementos simbólicos — hino e insígnia - concentra-se de maneira exemplar o sentido do martírio. Eles cumprem a função de reforçar, no plano emotivo, o valor do sacrifício. O hino, entoado todos os dias como parte de suas práticas rituais, afirma o sentido de filiação à organização e compromisso com ela. E a insígnia NUPALOM - presente em seus escudo, documentos, rituais - e as distintas formas através das quais o grupo se representa converteram-se num carimbo de identidade. Provavelmente, esses são os mecanismos mais potentes de recriação e socialização dessa concepção. Mas esses não são os únicos cenários. Outro âmbito em que se manifesta este tipo de pensamento é o dos documentos ideológicos:

O espírito do sacrifício e de entrega sem limite pela causa dos explorados foi visto em incontáveis companheiros e momentos da história do ELN [...] Essa firmeza de princípios, conhecida por nosso Povo, de muitos militantes da Organização consequentes com nossa insígnia NUPALOM, é inegável que forjou, para o ELN, um lugar definitivo na história e no coração de nosso Povo, e isso lhe outorgou a autoridade moral necessária para dirigir-se politicamente ao Povo e à esquerda revolucionária em particular (Compendio Simacota 1986:8).

Efetivamente, o mandato NUPALOM ocupa um lugar destacado no discurso político do grupo, como expressão máxima do nível de compromisso e "firmeza de princípios" com a causa revolucionária. Essa noção tornou-se um importante eixo de identidade, a partir do qual não só se têm construído como sujeitos sociais, como também forjaram um lugar de prestígio e autoridade moral diante do outro, o "povo", com quem buscam legitimar suas ações.

Também é possível encontrar importantes traços dessa visão em sua memória, na reconstrução de sua história. Nos diferentes estilos e meios através dos quais narram suas vivências, pode-se detectar a ênfase no valor do sacrifício, o qual se torna, em muitas ocasiões, fio condutor dos acontecimentos. Assim, por exemplo, cabe ressaltar a versão oficial de sua história, feita pelo militante (falecido) Milton Hernández, na qual se encontram vários fragmentos dedicados aos "mártires" da organização, especialmente no capítulo 65, intitulado "Os filhos de Camilo somos de libertação ou morte": 
Nessa utopia tão vivida, tão real e possível, se comprometeram e por ela deram até seu último fôlego. Essa cota de sangue generosa começamos a pagá-la desde Simacota [...] Vocês, camaradas, não estão mortos porque estão presentes com seu exemplo em cada um de nós [...] Honra e glória para todos os nossos heróis e mártires, e que seu exemplo guie para sempre nosso caminho! (Hernández 2006:459-463).

Provavelmente, uma das mais significativas expressões, emotivas e permanentemente recriadas no interior do grupo, seja a produção musical própria, na qual rendem efusiva homenagem aos seus mortos, como podemos apreciar nos seguintes trechos musicais:

Embora passem os dias e os anos

Segue lutando aquele que assim caiu

Enquanto lançava o último suspiro

Gritava vivas à revolução

(Avelino Bautista NRB, corrido)

Morreu mas segue vivo

Vivo na revolução

(Al Tío Jaime, NRB, corrido-vals)

Mas, avançando na compreensão dessa perspectiva sacrificial no ELN e, especialmente, no valor da morte como fato desencadeante, cabe ressaltar as reiteradas afirmações em suas falas sobre este tópico, tais como "morreu, mas segue vivo na revolução", ou "quem deu a vida pela causa sobrevive", nas quais se evidencia um claro sentido de transcendentalidade. Pois, em sua concepção, quem morre lutando em nome da "causa" realmente não morre, continua vivendo nos demais que permanecem na luta. Segue presente numa nova dimensão, na de "mártir", de ser exemplar fiel aos princípios (justos, altruístas) e chega até o final: a entrega total. Nessa condição especial, conquista a eternidade no mundo dos vivos, um lugar privilegiado da memória que, por suas características singulares, poder-se-ia afirmar, toca os fios do sacro, do superior, do modelo a seguir e de alguma maneira a idolatrar. Esse é, então, o lugar reverencial que têm os mortos na organização:

Quando se fala dos mortos, as pessoas fazem silêncio, um cálculo da dimensão da dor, da tragédia, mas isso fortalece, isso não diminui, tudo isso leva a que se fortaleça a convicção e o compromisso. A morte constitui praticamente uma das honras mais profundas, o respeito a que a entrega total, que é sua morte, 
é um ato crucificado e isso ressuscita em termos de compromisso porque é um valor. É tão profundo e sagrado que, se você o trai, trai atos sagrados, como seus mortos (Rosa, camponesa, 15 anos de militância).

Há suficientes elementos que indicam a relevância do sacrifício entre os elenos, inclusive, como foi visto acima, no sentido do sagrado. Assim, parece oportuno realizar uma aproximação conceitual com tal fenômeno e, nessa direção, a abordagem de Marcel Mauss e de Henri Hubert (2001) parece ser uma opção interessante para pensar a lógica do sacrifício. A tese central dos autores é a de que, apesar da diversidade de rituais sacrificiais, neles prevalece uma unidade de ação que consiste em "estabelecer uma comunicação entre o mundo sagrado e o mundo profano por intermédio de uma vítima, isto é, de uma coisa destruída no decorrer de uma cerimônia" (2001:223).

Em tal perspectiva, o sacrifício cumpre o papel de mediação entre o mundo sagrado e o mundo profano (Teixeira 1993:167), estabelecendo contato entre essas duas ordens de realidade e, por conseguinte, mobilizando certas forças que são necessárias em determinados contextos sociais. Esse seria o princípio reitor que determina a lógica do sacrifício. Um princípio que se atualiza e cujo conteúdo muda no decurso da história. Assim, por exemplo, durante um longo período prevaleceu uma noção prosaica e materialista que buscava "obter dos deuses benefícios muito precisos", passando a uma versão mais espiritual com fins transcendentais: a "salvação das almas", a "imortalidade", o "paraíso", tal como é concebido pelas grandes religiões históricas (Mauss 2003; Caillé 2002).

O caso aqui estudado, os militantes "caídos em combate", faria parte deste último tipo de sacrifício orientado pelos fins transcendentais. E, da mesma forma que todo ato sacrificial, realizaria uma mediação entre o mundo profano e o sagrado. Só que, neste caso, seria levado a cabo através deles mesmos, de sua morte violenta, como mecanismo de ativação da ponte de comunicação e interação entre esses mundos. Neste sentido, eles seriam vítimas e sacrificantes ao mesmo tempo, numa unidade dialética e complexa que muda de natureza, passando do estado profano ao domínio do sagrado (Mauss 2003), e ingressando, assim, numa nova categoria social: a de mártires. Esse protótipo se converte, desta maneira, num modelo ideal com o qual o coletivo estabelece formas de identificação com base numa visão de mundo compartilhada. Também cabe ressaltar que nessa condição especial adquirem poder - o poder dado pelo sagrado e o transcendente que transmitem e irradiam ao mundo profano.

Levando em consideração os anteriores elementos, é possível inferir, quanto ao rito sacrificial, que esse fenômeno comporta uma dinâmica de 
entrega e retribuição, de mobilização de forças e tributos, cuja dimensão de troca permite certa inflexão nesta análise. De fato, o estudo de Marcel Mauss e Hurbert sobre o rito de sacrifício aponta a existência de uma lógica implícita de reciprocidade:

Se o sacrificante dá alguma coisa de si, ele não se dá; ele se reserva prudentemente. É que, se ele dá, em parte é para receber. O sacrifício se apresenta sob um duplo aspecto. É um ato útil e uma obrigação. O desinteresse se mistura aí com o interesse. Daí porque com tanta frequência foi tão amiúde concebido sob a forma de contrato. No fundo, talvez não haja sacrifício que não tenha alguma coisa de contratual (Mauss \& Hubert 2001:225).

Ainda que no Ensaio sobre a dádiva Mauss não aprofunde esta questão, reitera a ideia do contrato preexistente no rito sacrificial: "a destruição do sacrifício tem precisamente como finalidade ser uma doação que há de ser necessariamente retornada" (Mauss 2001:172). Por outro lado, no âmbito dos estudos contemporâneos, vários autores têm proposto o debate em torno do tema da reciprocidade e do sacrifício, dando continuidade à reflexão inaugurada por Mauss. Nessa via, alguns matizes devem ser levados em consideração, como, por exemplo, o enfoque de Maurice Godelier (2001), que entende o sacrifício como uma dívida eterna dos humanos com Deus e, sob essa condição, não existiria retribuição possível; logo, a lógica da reciprocidade, em termos maussianos, seria impossível de aplicar. Outro enfoque interessante é aquele proposto por Allain Caillé (2002) que, diferentemente de Godelier, leva a discussão do sacrifício para o campo teórico da reciprocidade/dádiva. Ao indicar o limite presente na teoria do sacrifício de Hubert e Mauss, Caillé observa que esta deveria ser reinterpretada à luz da obra maussiana Ensaio sobre a dádiva. Sugere, desse modo, reformular tais noções traduzindo-as para a linguagem do dom (Caillé 2002:166).

Depreende-se da abordagem destes autores certa polarização em torno da complexa questão do sacrifício. De um lado, a ênfase no sentido da dívida eterna, sem possível retribuição; de outro, a ênfase no sentido da reciprocidade, entendida como o movimento do dom e contradom. Mas, indo para além dessa dicotomia, na presente análise busca-se situar o debate no nível do diálogo entre o campo teórico do sacrifício e o da reciprocidade, compreendendo-os segundo uma singularidade ontológica que os diferencia e, simultaneamente, os coloca diretamente imbricados. Nessa direção, o material etnográfico foi bastante sugestivo. Tudo indicava a existência de uma forma de reciprocidade implícita no sacrifício dos "caídos em combate". De maneira inequívoca, aparece em primeiro plano a premissa da entrega 
absoluta à causa revolucionária. No entanto, por mais altruísta que tal ato se mostre, não está isento de interesse: há, no fundo, uma busca de compensação. Aspiração que, como os próprios elenos apontam, não pertence à ordem do material nem do imediato:

O que acontece quando se morre? Já não vou para o céu, calma companheiro, aqui iremos louvá-lo: companheiro Rodrigo, presente! Até quando? Até sempre. Quando vou morrer? Quando já ninguém se lembre de mim. Transformemos a imortalidade da alma para imortalizar-nos em nossas ações. Mas, no fundo, está o tema da transcendência, todos nós queremos transcender (Mario, camponês, 18 anos de militância).

Esse ato de entrega aparentemente desinteressado está, na verdade, assentado sobre uma lógica de compensação, mas difere daquela verificada no interior das relações sociais mais amplas. Há uma mudança significativa na natureza da relação que se estabelece quanto às partes envolvidas, aos objetos trocados, ao seu direcionamento e ao tempo em que a troca se efetiva. Logo, o tipo de troca que se forma adquire outra dimensão. Torna-se mais acentuada e contundente. Por um lado, há a exacerbação da dimensão da entrega; por outro, a "amplificação ao máximo do interesse calculado" (Caillé 2002:168). Assim, na esteira dessas ideias e tendo em conta as citações anteriores, compreende-se a ação dos "caídos em combate" como um ato máximo de entrega, cuja oferenda é dar-se a si mesmo, e sem reservas, à causa revolucionária. E, pela oferta da própria vida, esperam receber benefícios também supremos, absolutos, sem possibilidade de comparação: por um lado, a "eternidade" através de sua lembrança na memória e nas ações dos companheiros de luta, e por outro, contribuir para a "salvação" do social. Nesta perspectiva, "caídos em combate" pode ser entendida como a mais alta expressão simbólica e ritual dessa disposição de entrega em prol dos ideais de salvação e justiça social.

Claro que no contexto de um universo social concebido como laico mudam os sujeitos da relação do sacrifício e da reciprocidade, pois ela já não se estabelece - assim como acontece no interior das comunidades religiosas entre os seres humanos, pertencentes à ordem do imanente, e Deus, pertencente à ordem do transcendente, mas entre os "caídos em combate" e os companheiros de luta que continuam vivos. Ainda que os dois pertençam ontologicamente ao mundo profano, com o ato do sacrifício os primeiros mudam de estado, ingressando na esfera do transcendente. Eis a correlação de esferas que se reconfiguram de acordo com esse contexto, mantendo-se a relação de troca e de reciprocidade que se estabelece entre os sujeitos em 
menção, e em que o fato gerador é o sacrifício através do qual se forma um pacto tácito muito forte entre eles. Os que morrem pela "causa" entregam seu tributo - sua vida - e criam, assim, uma dívida entre os que permanecem vivos, que se sentem comprometidos e obrigados perante esses mortos; uma obrigação que se torna necessidade imperiosa de retribuí-la:

Eu posso morrer, mas se sigo vivendo nos demais é porque isso segue com os demais, ali é onde sentimos que alguém não pode trair tudo isso [...] Ah, que alguém diga que uma rendição, que uma desmobilização é isso, mas, como alguém pode trair seus mortos? Quando eles morreram confiando em que eu era aquele que os seguia, que íamos até culminar no triunfo (Raul, camponês, 20 anos de militância).

Assim se forma a dinâmica da reciprocidade: na obrigação criada nos companheiros de luta de devolver esse dom recebido, como um compromisso forte, iniludível, cuja falta de cumprimento é vista como uma "traição aos mortos". Aqui é importante assinalar que na ética da militância a traição é considerada como uma das piores e mais condenáveis condutas. Com efeito, por essa lógica da retribuição, os contradons esperados por parte dos companheiros de luta são: o compromisso com a revolução, continuar "firmes" a luta iniciada pelos antecessores, ir até o fim, ou seja, "libertar o povo", ainda que isso implique dar suas próprias vidas (como o fazem os sacrificados) e manter viva a memória dos "caídos em combate", o que se materializa através de diversas estratégias, como: a) pôr seus nomes nas frentes ou nos destacamentos de combate, uma prática bastante importante e difundida dentro da organização, tanto que, segundo os dados apontados por Mario Aguilera (2007), das 53 estruturas de combate que havia em 1997, 32 tinham nomes alusivos a guerrilheiros mortos em combate; b) denominar determinados eventos ou datas comemorativas com os nomes desses combatentes; c) dedicar-lhes canções; d) rememorá-los nos documentos e nos diversos materiais de comunicação e divulgação; e) lembrá-los emotivamente nas insígnias "companheiro [...] caído em combate, Presente! Até quando? Até sempre!".

Da sua parte, eles recebem o exemplo dos que se sacrificaram, mas também, como já dito, certo poder que deriva da condição de sacralidade que adquirem os mártires e que, de alguma maneira, contagia o mundo profano, os que seguem o caminho da luta. Aí reside sua força e sua eficácia simbólica.

Nos elementos acima descritos podemos apreciar o caráter duplo da reciprocidade, que se manifesta como um ato "voluntário, aparentemente livre e gratuito" e, ao mesmo tempo, "obrigado e interessado" (Mauss \& 
Hubert 2001:157). Pois, embora o ato de sacrifício seja de natureza aparentemente desinteressada, altruísta e voluntária, por trás disso há um interesse para si (o sacrificante) e um sentido de obrigação para com o/s outro/s (os militantes) que entram na troca.

Assim, ainda que pareça uma troca eventual e desconexa, ela está, na verdade, inserida na lógica da reciprocidade, conservando uma linha de continuidade, embora se situe numa escala diferenciada de tempo e, por sua longa duração (mais de 40 anos de luta), abarque sujeitos de distintas procedências, idades e gerações. Cumpre notar que essa troca não se restringe ao nível do individual. A pessoa que se sacrifica nesse ato não o faz motivada por uma causa pessoal nem está em busca de uma recompensa individual. Ela entrega sua vida por uma causa social e espera, em troca, uma recompensa maior: a "libertação social". Dessa maneira, incorpora-se o coletivo na dinâmica da reciprocidade, no caráter extensivo da dádiva e em seu obrigatório retorno. Uma dinâmica que ativa o ciclo do dom e do contradom em diferentes tempos e corporeidades, como um poderoso mecanismo de integração social através da formação de alianças fundamentadas no compromisso com uma dívida histórica em face dos sacrificados pela "causa", que condiciona a conduta e reforça o sentido de filiação e pertença ao grupo.

\section{O exército dos mortos}

O exército dos mortos parece uma denominação perfeita para designar a forma como os elenos entendem e ressignificam simbolicamente os guerrilheiros caídos em combate, pois eles, na verdade, parecem estar mais presentes que muitos dos presentes. Eles inauguram os eventos, encerram o momento ritual, solene, da formação no pátio de bandeiras, encabeçam as estruturas político-militares que levam seus nomes, são cantados e aclamados nos distintos encontros e, como os elenos expressam, "não estão mortos", continuam vivos na memória, uma memória que se atualiza e se vivencia dia após dia.

Eles seguem tão "vivos" que são até mesmo incorporados na lógica de classificação hierárquica da organização. Os mortos, reivindicados, por seus atos heróicos, como corresponde a seu sistema de valoração, são reclassificados nessa nova "condição existencial" conforme seu sistema de graus póstumos, que consiste numa graduação de cinco níveis hierárquicos, a saber: 1. "Comandante em Chefe", outorgado aos comandos considerados como os máximos guias da organização; 2. "Comandante", reconhecimento dado aos comandos que também encarnam o ideal do ser eleno, mas que não 
chegaram ao nível dos "profetas"; 3. "Capitão", distinção correspondente ao nível dos militantes rasos que também demonstraram heroísmo; 4. "Capitão Comunheiro", outorgado aos militantes que atuaram no âmbito amplo do político e do social; e 5. "Combatente Comunheiro", definido nos mesmos termos que o anterior com a diferença de que sua contribuição se deu no "nível regional" (Parágrafos 1-4, Estatutos 2006).

Observe-se que nessa reclassificação que fazem dos mortos é preservado o status que tinham em vida, conservando-se e estendendo-se até o mundo do além. Ingressam nesse outro mundo com as distinções que tinham no anterior, só que agora adquirem mais potência, à medida que realizam o ideal consagrado no princípio fundador do NUPALOM. Dessa maneira, a organização recria a condição da militância após a morte, com graus e distinções que não apenas reproduzem a hierarquia existente, mas se aprofundam nela. Porque eles, o "exército dos mortos", se revestem de maior prestígio e poder simbólico; eles se situam no topo da classificação hierárquica da organização.

$\mathrm{O}$ "exército dos mortos" não representa um dado alegórico, ele tem uma forte presença no campo de interação e na configuração hierárquica do ELN. Seus integrantes entram na posição mais alta do esquema de classificação e, uma vez ali, são investidos de poder, tornam-se os modelos ideais, os guias do caminho, os exemplos para imitar e dar continuação. Eles são invocados nos momentos difíceis como os referentes para alentar e sair das crises, são insígnias pedagógicas que afiançam a socialização dos militantes, sublimam o sentido da entrega total, e são, finalmente, os que ajudam a reforçar o compromisso dos militantes de não renunciarem diante das penúrias e das dificuldades, em virtude da dívida eterna contraída com os mortos, que os obriga a não traí-los.

\section{O ascetismo como estilo de militância}

O ascetismo é uma expressão do martírio, assumir o sofrimento como uma forma de "purificação" para alcançar a salvação, cujo significado deriva de um importante princípio da tradição cristã no qual se concebe que "também Cristo padeceu por vós, deixando-vos o exemplo para que sigais os seus passos" (São Pedro, $1^{a}$ Epístola, cap. 2:21). Essa forma de ver o mundo tem sido ativada em distintas épocas históricas e a partir de diferentes elementos significativos. Por exemplo, na Idade Média, quando se converteu numa doutrina hegemônica, foi um dos principais alicerces do poder religioso e moral e um mecanismo altamente eficaz de controle social. Assim, a "salvação 
das almas" se fazia através da vigilância do corpo, de seu estrito disciplinamento. Já no período da Reforma, e com os primeiros passos do capitalismo, produz-se um novo tipo de ascetismo, caracterizado por Max Weber (2000) como intramundano, quando essa prática deixa de ser um modo de buscar a salvação no além para passar a assegurar a salvação neste mundo, consequentemente, o controle sobre o corpo convertendo-se em uma forma de doutrinação para submeter os indivíduos à lei do capital. Este é, em grande parte, o fundamento da ética do protestantismo: o domínio do sujeito e de sua corporalidade em prol do incremento da produtividade.

Essa mesma lógica intrínseca ao ascetismo de origem cristã de controle do sujeito através do disciplinamento do corpo também está presente nos movimentos cristãos de tendência socialista e em boa parte dos movimentos revolucionários radicais. No primeiro caso, Enzo Pace (1983) faz uma sugestiva interpretação dos grupos católicos da região de Vêneto, Itália, das décadas de 1960 e 1970, assinalando que a prática política desses agrupamentos estava centrada no ascetismo, denominada pelo autor de "ascetismo selvagem", cujos princípios axiológicos giravam em torno do tema da pobreza e de uma crítica radical ao mundo capitalista. Nessa mesma direção, pode-se mencionar o movimento dos sacerdotes operários, uma vez que, além de ser um dos pioneiros nesse gênero, ${ }^{4}$ radicalizou a perspectiva do ascetismo com sua visão de "encarnar-se nos pobres", de compartilhar seus sofrimentos, sua condição de vida, e, inclusive, como afirma Dansette, "para a maior parte dos sacerdotes operários, não se é verdadeiramente um deles, enquanto a pessoa não se decida a sê-lo até a morte" (Dansette apud Pelliteiro 1997:319).

Também nos movimentos revolucionários radicais, e particularmente nas guerrilhas revolucionárias dos anos 1960-1970, percebem-se uma concepção e um estilo de militância fortemente influenciados pelo ascetismo, como forma de assegurar o autocontrole dos combatentes e ganhar legitimidade social:

[o guerrilheiro] deve ter uma conduta moral que o afirme como um verdadeiro sacerdote da reforma que pretende. À austeridade imposta pelas difíceis condições de guerra deve somar-se a austeridade nascida de um rígido autocontrole que impeça um único exceso, um único deslize [...] O soldado guerrilheiro deve ser um asceta (Guevara 1972:47).

O ELN configurou-se em torno destes dois modelos de comportamento. O da chamada "mística revolucionária", cujo principal referente é a Revolução Cubana e, especialmente, a imagem, eu diria, idolatrada de Che Guevara, que é estampada em diferentes objetos de uso pessoal e reforçada 
em muitos cenários grupais. E, por outro lado, a influência exercida pelo setor cristão, para o qual o ascetismo tem sido justamente um dos principais fundamentos de suas concepção e ação.

Durante os primeiros anos (1963-1974), essa pauta de conduta foi incorporada com um espírito bastante dogmático. O chefe máximo do ELN à época, Fabio Vásquez, reproduziu o Código do Guerrilheiro, manual elaborado durante o auge da Revolução Cubana e aplicado de maneira estrita nos distintos contextos de luta. Nele se normatizava o agir dos militantes e se penalizava com muito rigor o desvio dessas regras, de modo que se converteu na "lei" da vida guerrilheira. Uma lei cujo fundamento era seu ascetismo, ideal de conduta revolucionária, em função do qual se media o nível de compromisso com a luta. Por isso, muitas faltas e/ou infrações que se cometiam infringindo esse regimento eram consideradas como "traição à revolução" e, nessa medida, duramente penalizadas. Observemos o seguinte episódio sobre os primeiros anos da guerrilha, que oferece valiosos elementos etnográficos para pensar essa problemática:

Os treinamentos continuavam e dia a dia se tornavam mais repetitivos [...] A rotina nos destruía a todos. Um dia, Silvério se enfureceu porque já eram duas horas da tarde e estávamos sem comer [...] largou o fuzil e gritou para que todos ouvíssemos: "Que filhos da mãe, eu não faço mais PUM PUM, e se por essa merda vão brigar comigo, que briguem, mas eu vou ao acampamento buscar pelo menos uma banana para comer". Todos ficamos preocupados porque, segundo nosso código guerrilheiro, o que ele acabava de fazer era uma insubordinação [...] falaram a sós com Silvério, que fez uma autocrítica pública por sua atitude, logo Carlos notificou a todos que Silvério ficaria quatro dias de guarda como sanção por seu erro. À noite, Carlos e Andrés proferiram uma extensa palestra sobre a importância de acostumar o organismo a não comer muito, salvo consumir os alimentos necessários para a nutrição (Nicolás Rodriguez, romance, s.d.:27).

No relato é clara a punição diante da falta de controle de uma necessidade física: "comer", falta esta vista sob a lente do Código do Guerrilheiro como uma insubordinação e desvio moral. Esta é uma clara expressão do ascetismo que reprime as necessidades corporais como fundamento do modelo ideal do guerrilheiro. Um modelo no qual a abstinência não só é justificada, como convertida em virtude. Ainda que a organização levasse a cabo um processo de autocrítica da rigidez dos primeiros anos, tal como sublinha Nicolás, "esse estilo [de militância] foi se tornando um princípio" que permanece até hoje como modelo de referência. Como se interioriza essa perspectiva? 
Ali pode ser evidenciada a influência do chamado exemplo impecável, elevado à sua máxima expressão com o setor dos cristãos e especialmente com o sacerdote Manuel Pérez que, por meio de seu próprio testemunho de vida e luta, promove um estilo de militância marcadamente ascético e moral. Em Manuel se potencializa esse "modelo ideal" pelas condições especiais que possuía: de um lado, chefe máximo da organização por um longo período, que o convertia, segundo seu sistema interno de relacionamento, num "velho", isto é, uma espécie de pai afetivo com altos níveis de respeito e autoridade; de outro, por sua investidura de sacerdote, que lhe proporcionava certa auréola de sacralidade. Assim, o que antes chegava a ser questionado, na nova versão é enaltecido como o modelo de conduta.

Certamente, esta perspectiva foi levada à práxis, convertendo-se num estilo de trabalho político bastante radical, como, por exemplo, quando os militantes urbanos, movidos pela necessidade de se inserirem na classe popular, iam trabalhar nas fábricas, no serviço doméstico ou em qualquer outro tipo desses ofícios para sentirem neles próprios "o rigor do capitalismo", para "fazer parte do povo", numa exigência tal que "às vezes excedia nossa capacidade porque, além das duras jornadas laborais às quais nos submetíamos e a que a maioria de nós não estava acostumada, pois em nossas fileiras havia muitos profissionais e pessoas de classe média, também tínhamos que estudar à noite e, nos finais de semana, fazer proselitismo" (Rosa, militante urbana). Contudo, não se queixavam, porque estavam "convencidos de que essa era a forma de demonstrar o [seu] compromisso". Outro cenário onde se expressa essa postura de austeridade é no manejo dos recursos econômicos, como ocorreu nos anos 1980, quando, apesar da fartura em razão do ingresso do petróleo nas zonas que controlavam, fizeram uma rígida vigilância moral: "Vivíamos com muita penúria [...] Apenas tínhamos para comer e para mobilizar-nos nos trabalhos. E todas as moedas que sobravam transformavam-se em contas. Nunca havia dinheiro para nós, para nossas necessidades, fora das essenciais. Nunca uma diversão" (Laura, camponesa).

Ainda que, com o passar do tempo pareça atenuar-se esse tipo de comportamento, pois a militância já não vive sob esse tipo de radicalismos, na verdade, continua sendo um valor de muito peso apreendido no convívio cotidiano do grupo e especificamente na corporificação da experiência. O corpo se mostra, por múltiplas perspectivas sociais, como lugar privilegiado na construção dos sujeitos e das subjetividades. Nas sociedades ocidentais contemporâneas, fundamentadas na noção hegemônica do indivíduo, o corpo é entendido como o recinto objetivo da soberania do sujeito e fator 
essencial da individualização (Le Breton 1995). No entanto, no ELN, vivese outro sentido de corporalidade, contraposto a esse modelo hegemônico. O corpo se edifica sobre os valores do coletivo, em função do social, como um instrumento de que se dispõe em prol dos ideais da organização. $\mathrm{O}$ "corpo social" aparece, assim, como o ideal no qual se inscreve o processo de reconstrução corporal e subjetiva que ali tem lugar.

Essa noção da corporalidade adquire ainda mais relevância se tivermos presente a centralidade que ganha o corpo no processo de aprendizagem de certas técnicas especializadas, como a militar, pois no contexto da guerra os corpos não são secundários, eles se convertem numa arma fundamental, num meio através do qual os guerreiros atingem sua meta; são, de alguma forma, a "corporificação subjetiva" que se ativa no campo de batalha na busca de certos ideais. Daí o imperativo de controlar as exigências físico-corporais como condição essencial da luta guerrilheira. Esta afirmação parece óbvia, pois sabemos que para poder manter um projeto de luta como esse, na clandestinidade, sob riscos e com inúmeras dificuldades, é preciso um recondicionamento corporal que assegure a sobrevivência de seus membros.

No entanto, o diferencial importante a ser destacado é a forma como essas condutas corporais são vistas e assumidas: como virtudes, depositárias de um alto valor revolucionário que demonstram a capacidade de entrega do militante. Não é um simples problema racional de sobrevivência. Essas atitudes estão revestidas de uma carga moral, de nobreza, de dignidade. Em contrapartida, afastar-se desse modelo ideal implica cair em posições fortemente condenadas pelo grupo, não só punidas, mas também julgadas moralmente como uma "falta de compromisso com a revolução". Aí se raciocina a partir da lógica da dicotomia moralizante do indevido (impuro) e da proteção sublimada do ideal revolucionário (puro).

Assim sendo, tais valores, acrescidos dessa visão moral, atuam como potentes dispositivos simbólicos que reforçam o processo de aprendizagem dessas atitudes corporais. O corpo é visto como o meio de construção do social e projeção da utopia de luta. E, nessa direção, o corpo do sujeito adquire importância à medida que está à disposição dos interesses coletivos. Mas não apenas à disposição, pois também deve possuir as formas e as condições apropriadas para essa causa social. O corpo tem que ser treinado, preparado, adequado a essas novas requisições. Seus principais atributos são: ser forte, resistente, abstêmio, austero, estoico, sacrificado. É uma corporalidade trabalhada no físico, para adquirir as condições necessárias ao combate, e no psicológico/emocional, para ter a capacidade de resistir à luta e nela persistir. 


\section{Anotações finais}

Logo, dos argumentos esgrimidos, a questão que fica no ar é a razão pela qual essa visão do transcendente consegue se incorporar dessa forma no ELN. O que facilita sua apropriação? A esse respeito é importante esclarecer que tal fenômeno não pode se reduzir à influência do setor cristão e/ou ao poder simbólico da investidura eclesiástica no interior desta organização. Ali intervieram outros elementos de muito peso, como a preexistência de uma profunda religiosidade entre os militantes, aspecto que já tem sido identificado em processos revolucionários similares, e outras situações históricas nas quais se torna um componente fundamental na configuração das militâncias (Chaves 2002; Pace 1983; Ertel 2003). Para o caso colombiano, é possível afirmar que a religiosidade faz parte de seu ethos, de um universo significativo em cujo âmbito o cristianismo, os valores e a matriz de significados que ele envolve ainda fazem sentido.

Na verdade, tem a ver com uma forma de identificação, com uma lógica compartilhada, assentada na tradição católica da população colombiana, de modo que o estilo de militância do ELN ativa referentes altamente potentes dessa concepção religiosa, como a classificação simbólica do corporal impuro (sujo), que subjaz ao conjunto de normas e formas de disciplinamento físicas e morais, princípios do sofrimento e do martírio, como meios para alcançar os altos ideais que perseguem: a "libertação do povo" (sua salvação) e uma "sociedade justa" (o paraíso na terra), e uma noção que não se pode deixar passar, a "eternidade", que sintetiza muito bem o sentido de tempo que a organização possui.

Essa noção está diretamente relacionada com a premissa fundamental de luta: ir até o fim do fim, mesmo que isso custe a vida. Nessa ordem de ideias, a eternidade estaria contida no "sem tempo" de chegar ao "fim dos tempos", ou seja, a "libertação". Esta é a meta, o sonho, que avigora a utopia de luta. É um tempo que se inicia com a conquista espanhola, tal como é expresso na primeira estrofe de seu hino: "É América o cimento milenar/De Colômbia e nossa história nacional/Onde indígenas e escravos iniciaram/As batalhas contra o jugo colonial". Um tempo que vem desse "jugo colonial" e que vai até a supressão dele, até a realização de seu grande ideal: a sociedade justa, igualitária, socialista. Esse tempo, construído e vivenciado por eles, aparece bem claro em seus diferentes discursos:

Nosso sonho é realizar a utopia conjunta dos operários, camponeses e do povo de fazer da Colômbia um lugar feliz. Um lugar feliz. Três simples palavras que encerram um desafio enorme, quase impossível, mas alcançável. Não são as 
obras impossíveis, senão os homens incapazes. Essa inquebrantável decisão de lutar até vencer foi uma constante em toda a nossa peregrinação pela vida e pela causa. Com cada derrota, cresce o ímpeto [...] cada vitória é um novo impulso para avançar [...] Quando decidimos fazer guerra contra a injustiça, estávamos trilhando um destino que já não podia ser detido e que vai mais além, inclusive, da própria vontade dos homens (Hernandez 2006:297).

Neste texto podemos perceber a intensidade com que são colocados os termos de seu projeto de luta, como um desafio imenso, "quase impossível", um caminho cheio de dificuldades que, antes de levar ao desânimo, aviva o "ímpeto" de continuar porque esse é o "destino" que já está marcado para além da "própria vontade dos homens". Esta concepção desvela, assim, um transcendente que os governa, que pauta o caminho que devem seguir e do qual não podem fugir. Ainda que eles decidam "fazer guerra à injustiça" como um ato derivado da vontade humana, esse ato parece ativar uma força que os potencializa, mas que também os controla. Nessa ordem de ideias, pode-se entender que a visão da história está tecida por esse sentido de temporalidade "sem tempo", com um fundo salvacionista, em que as derrotas e as dificuldades são percebidas como um tipo de provas de seu "heroísmo", um heroísmo inspirado e alimentado pela fortaleza da utopia. Assim, à vista desses elementos, poder-se-ia afirmar que o significado do tempo no ELN é vivenciado num sentido escatológico, conforme assinala Pattaro:

A história cristã não está no tempo apesar do tempo, mas concebe-o como uma libertação, a tal ponto que o passado se apresenta sempre como uma possibilidade de futuro e o que acontece aguarda sempre o seu "depois" como possibilidade real [...] É o tempo em que "se vem de" a fim de "ir para"; é o tempo de uma fé que garante e faz nascer uma esperança que transforma o tempo e todos os acontecimentos nele ocorridos para transformá-lo numa expectativa cheia de sentido (Pattaro 1975:199-228).

Esta concepção estaria também apontando para o que Jean Delumeau afirma em relação à história das utopias e dos milenarismos no Ocidente, no sentido de que, em que pesem as diferentes versões e os distintos contextos espaço-temporais, em todas as escatologias prevalece uma base comum: o mito religioso do paraíso que evoca elementos simbólicos bastante internalizados, isto é, o mundo final e eterno de felicidade, a abundância, o reino da justiça e, em geral, o bem-estar coletivo. Estaria evidenciando, então, a nostalgia do "paraíso perdido" recriado ao longo da história. E se temos 
presente, conforme Delumeau, que "modernidade e milenarismo não são necessariamente excludentes" (1997:13), podemos entender que a nostalgia do paraíso no mundo laico se converte em renovada expressão de esperança e busca de novos paraísos terrenos, edificados pelos homens, que conservam, porém, os ideais nutridos pelo mito originário. Eis a utopia social que subjaz ao comunismo, paradigma fundacional do ELN, que se assenta na sentença radical da história: "A ação do proletariado suprimirá a exploração do homem pelo homem e o enigma da história será resolvido" (Marx 1959 apud Delumeau 1997:322). Assim, com a superação da exploração por meio da luta revolucionária, se passaria ao comunismo, ou seja, ao novo paraíso, "um lugar feliz" na perspectiva dos elenos, como ponto culminante da história e da realização escatológica.

Recebido em 15 de fevereiro de 2011

Aprovado em 16 de agosto de 2012

Andrea Lissett Pérez é doutora em antropologia social. E-mail: <andreaperez71

@hotmail.com>

\section{Notas}

* O presente artigo se baseia na minha tese de doutorado "O sentido de ser guerrilheiro: Uma análise antropológica do Exército de Libertação Nacional da Colômbia", apresentada em 2008 no Programa de Pós-Graduação em Antropologia Social da UFSC.

${ }^{1}$ Durante o trabalho de campo, anos 2006 e 2007, a Colômbia era governada pelo presidente Álvaro Uribe, que iniciava seu segundo mandato presidencial. A política que caracterizou esse período foi a da "seguridade democrática", com fortes confrontações militares contra as guerrilhas, além da presença ainda ativa de organizações armadas ilegais, os "paramilitares", que intensificaram o nível do conflito armado interno neste país. O ELN foi expulso de vários territórios que historicamente dominava e seu corpo armado apenas chegava apenas a 3 mil militantes. Apesar disso, em seu último Congresso Nacional, em 2006, o grupo declarou-se em fase de "reafirmação", confirmando sua decisão de "manter-se firme em seus propósitos centrais de luta" (Revista Simacota, IV Congreso 2006:29). 
${ }^{2}$ Os estudos dominantes no campo do conflito armado na Colômbia abordam, fundamentalmente, os aspectos políticos e/ou militares, deixando de lado as dimensões sociais e culturais que ficam relegadas a simples referências ou a dados do contexto, não sendo tomadas como argumentos explicativos.

${ }^{3}$ Camilo Torres Restrepo nasceu em 1929 no seio de uma família burguesa, ordenou-se como sacerdote em 1954 e doutorou-se em Sociologia na Universidade Católica de Lovaina (1958). Vinculou-se como capelão da Universidade Nacional de Colômbia em 1959, onde fundou, em 1960, junto com Fals Borda, o Departamento de Sociologia. Por seu ativismo político em prol dos setores populares, entrou em conflito com as hierarquias eclesiásticas, situação que gerou seu abandono do sacerdócio em 1965, ano em que se vinculou à guerrilha do ELN. Morreu no dia 15 de fevereiro de 1966 no primeiro combate de que participou. É considerado um dos pioneiros do movimento da teologia da libertação na América Latina.

${ }^{4}$ Esse movimento eclesial, de tendência marxista, nasceu na França em 1944 e se estendeu pela Espanha nos anos 60. Com base na premissa de fazer presente a libertação do evangelho, esses sacerdotes decidiram inserir-se e trabalhar no mundo dos operários, compartilhando-o com eles, com o fim de melhorar suas condições de vida.

\section{Referências bibliográficas}

AGUILERA, Mario. 2007. "ELN: entre las armas y la política". In: F. Gutiérrez (org), Nuestra guerra sin nombre. Transformaciones del conflicto en Colombia. Bogotá: Norma. pp. 209-266. ARENAS, Jaime. 1971. La guerrilla por dentro. Análisis del ELN Colombiano. Bogotá: Tercer Mundo.

BOFF, Leonardo. 1996. "As bodas de prata da Igreja com os pobres: a Teologia da Libertação". In: L. Boff, J. Ramos \& C. Boff (orgs.), A Teologia da Libertação. São Paulo: Ática. pp. 9-16.

CAILlÉ, Alain. 2002. Antropologia do dom: o terceiro paradigma. Petrópolis: Vozes.

CAMURÇA, Marcelo. 1998. "Imaginário, símbolos e rituais nos movimentos e organizações comunistas: por uma antropologia interpretativa da esquerda". Religião e Sociedade, 19 (1): 27-40.

CHAVES, Christine. 2002. "A Marcha Nacional dos Sem-terra: estudo de um ritual político". In: M. Peirano (org.), O dito e o feito. Rio de Janeiro: Relume Dumará. pp. 133-148.

DELUMEAU, Jean. 1997. Mil anos de felicidade: uma história do paraíso. São Paulo: Companhia das Letras.

DUMONT, Louis. 1992. O individualismo. Uma perspectiva antropológica da ideologia moderna. Lisboa: Publicações Dom Quixote.

ERTEL, Rachel. 2003. Braisier de mots. Paris: Liana Levi. 
GAUCHET, Marcel. 2004. Un monde désenchanté? Paris: Les Éditions de l'Atelier.

GODELIER, Maurice. 2001. O enigma do dom. Rio de Janeiro: Civilização Brasileira.

GUEVARA, Ernesto. 1972. Obra revolucionaria. México: Era.

HARNECKER, Marta. 1988. Unidad que multiplica: entrevista a dirigentes máximos de la Unión Camilista Ejército de Liberación Nacional. Quito: Quimera Ediciones.

HERNANDEZ, Milton. 2006. Rojo y negro. Bilbao: Tafalla.

LE BRETON, David. 1995. Antropología del cuerpo y modernidad. Buenos Aires: Nueva Visión.

MCADAM, Doug. 1994. "Cultura y movimientos sociales". In: E. Laraña \& J. Gusfield (orgs.), Los nuevos movimientos sociales. De la ideología a la identidad. Madrid: CIS - Centro de Investigaciones Sociológicas. pp. 43-68.

MAUSS, Marcel \& HUBERT, Herbert. 2001. "Ensaio sobre a natureza e função do sacrifício". In: M. Mauss (org.), Ensaios de sociologia. Perspectiva: São Paulo. pp. 141-227.

MAUSS, Marcel. 2003. "Ensaio sobre a dádiva: formas e razão da troca nas sociedades arcaicas". In: M. Mauss (org.), Sociologia e antropologia. São Paulo: Cosac \& Naify. pp. 167-246.

PACE, Enzo. 1983. Ascetti e mistici: una societa secolarizatta. Venecia: Marsilio Editori.

PATTARO, Germano. 1975. "A concepção cristã do tempo". In: P. Ricoeur et al. (orgs.), As culturas e o tempo. São Paulo: Vozes. pp. 197-228.

PELLITEIRO, Ramiro. 1997. Sacerdotes seculares hoy. Planteamientos, reflexiones y propuestas sobre la secularidad de los presbíteros. Madrid: Libros Palabra.
PEREZ, Andrea. 2006. "Novas trilhas do paraíso: o rasto do religioso na contemporaneidade". Sociedade e Cultura, 9(1):39-50.

SOARES, Luiz. 1990. "O trabalho da inércia: história e teologia na formação da subjetividade moderna". Religião e Sociedade, 15(2-3):170-192.

TEIXEIRA PINTO, Márnio. 1993. “Marcel Mauss: o sacrifício e a dádiva". In: F. Paz (org.), As aventuras do pensamento. Curitiba: UFPR. pp. 139-171.

TORRES, Camilo. 1970. Cristianismo y revolución. México: Era.

VELHO, Otávio. 1995. Besta-fera: recriação do mundo. Ensaios críticos de antropologia. Rio de Janeiro: Relume Dumará.

WEBER, Max. 2000. Sociologia da religião. Economia e sociedade. Brasília: UnB.

\section{Documentos internos ELN}

ARROYABE, Bernardo. 1996. Carta.

Compendio Simacota. 1985.

Revista Simacota. 2006.

Conclusiones II Congreso. 1990.

Cuadernos del Militante, IV Congreso. 2006.

O. Romero. 1986. Documento.

Estatutos ELN III Congreso. 1996.

Estatutos ELN IV Congreso. 2006.

Insurrección. 1972.

LADIN, Domingo. 1970. Carta Abierta.

RODRIGUEZ, Nicolás (Gabino). s.d. Y nos hicimos guerrilleros. Romance. . 2002. Intervención Radial Nacional. 


\section{Resumo}

Neste artigo discuto a força do religioso na constituição identitária da guerrilha revolucionária da Colômbia, o Exército de Libertação Nacional (ELN), surgida em 1964 e ainda vigente como projeto de luta armada. Embora o ELN se defina como uma organização ateia, seguidora dos princípios do marxismo-leninismo, a morte em combate do sacerdote Camilo Torres ativou um dos princípios germinais da tradição cristã no interior do grupo: o sacrifício de Jesus pela humanidade, mensagem traduzida para a linguagem da luta social e convertida em premissa de luta. Essa visão sacrificial perpassará os distintos contextos, práticas, formas expressivas e discursos do mundo dos elenos. Constitui-se num elemento estruturante e significante da identidade do grupo.

Palavras-chave Religiosidade, Guerrilha, ELN, Sacrifício, Transcendência.

\section{Abstract}

In this article I discuss the strength of the religious in the identifiable constitution of the Colombian revolutionary guerrilla (ELN) national liberation army, arisen in 1964 and yet in force as an army struggle project. Although the ELN defines itself as an atheist organization that follow the Marxism-Leninism principles, the dead in combat of the priest Camilo Torres activated one of the germinal principles of the Christian traditions to the inner of the group: Jesus sacrifice by humanity, it is a message translated to the social fight and converted in straggle premise. This sacrifying vision will pass by the distinct contexts, practices, ways of expression and lectures from the elenos world that bind itself into a significant and structural element of the identity of the group.

Key words Religiosity, Guerrilla, ELN, Sacrifice, Transcendence. 